\title{
Plant functional types define magnitude of drought response in peatland $\mathrm{CO}_{2}$ exchange
}

\author{
Jan J. Kuiper, ${ }^{1,2}$ Wolf M. MooiJ, ${ }^{1,3}$ Luca Bragazza, ${ }^{4,5,6}$ and Bjorn J. M. Robroek ${ }^{2,4,5,7}$ \\ ${ }^{1}$ Department of Aquatic Ecology, Netherlands Institute of Ecology (NIOO-KNAW), 6708 PB Wageningen, The Netherlands \\ ${ }^{2}$ Ecology and Biodiversity Group, Institute of Environmental Biology, Utrecht University, $3584 \mathrm{CH}$ Utrecht, The Netherlands \\ ${ }^{3}$ Aquatic Ecology and Water Quality Management Group, Wageningen University, 6700 AA Wageningen, The Netherlands \\ ${ }^{4}$ École Polytechnique Fédérale de Lausanne (EPFL), School of Architecture, Civil and Environmental Engineering (ENAC), \\ Laboratory of Ecological Systems (ECOS), Station 2, CH-1015 Lausanne, Switzerland \\ ${ }^{5}$ WSL, Swiss Federal Institute for Forest, Snow and Landscape Research, Research Unit Community Ecology, Site Lausanne, \\ Station 2, CH-1015 Lausanne, Switzerland \\ ${ }^{6}$ University of Ferrara, Department of Life Science and Biotechnologies, Corso Ercole I d'Este 32, Ferrara 44121 Italy
}

\begin{abstract}
Peatlands are important sinks for atmospheric carbon (C), yet the role of plant functional types (PFTs) for $\mathrm{C}$ sequestration under climatic perturbations is still unclear. A plant-removal experiment was used to study the importance of vascular PFTs for the net ecosystem $\mathrm{CO}_{2}$ exchange (NEE) during (i.e., resistance) and after (i.e., recovery) an experimental drought. The removal of PFTs caused a decrease of NEE, but the rate differed between microhabitats (i.e., hummocks and lawns) and the type of PFTs. Ericoid removal had a large effect on NEE in hummocks, while the graminoids played a major role in the lawns. The removal of PFTs did not affect the resistance or the recovery after the experimental drought. We argue that the response of Sphagnum mosses (the only PFT present in all treatments) to drought is dominant over that of coexisting PFTs. However, we observed that the moment in time when the system switched from $\mathrm{C}$ sink to $\mathrm{C}$ source during the drought was controlled by the vascular PFTs. In the light of climate change, the shifts in species composition or even the loss of certain PFTs are expected to strongly affect the future C dynamics in response to environmental stress.
\end{abstract}

Key words: drought; net ecosystem $\mathrm{CO}_{2}$ exchange; peatlands; plant functional types; recovery; resistance; Sphagnum.

\section{INTRODUCTION}

The extensive amount of organic carbon $(\mathrm{C})$ stored in northern peatlands has been shown to be highly vulnerable to increasing soil temperature (Freeman et al. 2001a, Piao et al. 2008, Dorrepaal et al. 2009) and decreasing soil moisture (Freeman et al. 2001b, Fenner and Freeman 2011). In particular, prolonged periods of drought can significantly impact the structure and the functioning of peatlands (Weltzin et al. 2003, Bragazza 2008), which then can (temporarily) shift from $C$ sinks to C sources (Lafleur et al. 2003, Lund et al. 2012). The adverse effects of drought on the peatland $\mathrm{C}$ balance may, however, strongly depend on plant community composition (Johnson et al. 2011), and the co-occurrence of species or plant functional types may help maintaining ecosystem processes in response to disturbance (Mulder et al. 2001, Craine et al. 2012).

Manuscript received 14 February 2013; revised 23 May 2013; accepted 25 June 2013. Corresponding Editor: R. A. Dahlgren.

${ }^{7}$ Corresponding author. Ecology and Biodiversity Group, Institute of Environmental Biology, Utrecht University, Padualaan 8, $3584 \mathrm{CH}$ Utrecht, The Netherlands.

E-mail: bjorn.robroek@epfl.ch
The role of plant species richness and diversity for the stability of ecosystems in response to environmental changes is heavily debated (Loreau and de Mazancourt 2013). Generally, high species diversity and high diversity in traits promotes nonadditive effects on ecosystem services due to complementarity, facilitation, and competition between species or species groups (Hooper et al. 2005, Dias et al. 2013). More evidence is provided that species richness promotes the stability of ecosystem processes (Hector et al. 2010, Isbell et al. 2011, Bloor and Bardgett 2012). Alternatively, the stability of ecosystems is suggested to be mainly driven by the most dominant species, or species group, and to be proportionate to the primary production of these species (Grime 1998).

Mosses of the genus Sphagnum, generally dominate ombrotrophic peatlands, or bogs, and their decayresistant litter makes the bulk of the stored peat (Hájek et al. 2011). Due to their ability to modify their environment, Sphagnum mosses are considered typical ecosystem engineers (Rochefort 2000). Consequently, Sphagnum mosses reduce the potential success of competing plant species (van Breemen 1995, Rydin and Jeglum 2006). Additionally, through their high polyphenol content, Sphagnum mosses inhibit microbi- 
al activity by which they control decomposition processes and thus the export of $\mathrm{C}$ from peatlands (Bragazza and Freeman 2007). Vascular plant species, with different functional traits, are typical inhabitants of bogs (Chapin et al. 1996), where plant communities are reported to be remarkably stable in terms of species composition for long periods (Backéus 1972, Rydin and Barber 2001). Studies at species level (Robroek et al. 2007, 2009, Otieno et al. 2009), community level (Alm et al. 1999, Bubier et al. 2003, Laine et al. 2007, Ward et al. 2009) and ecosystem level (Deppe et al. 2010) revealed that biota play a decisive role in controlling peatland $\mathrm{C}$ dynamics. The apparent protective role of vascular plant species on moss growth and $\mathrm{C}$ uptake has previously been described. Photo inhibition of photosynthesis, for example, under high irradiance has been reported to decrease under shading due to vascular plant cover (Murray et al. 1989, 1993), and shading by vascular plants may additionally decrease moss evaporation and protect the moss canopy from drying (McNeil and Waddington 2003, Heijmans et al. 2004). Few studies, however, have explicitly studied the role and function of different plant functional groups on peatland $\mathrm{C}$ uptake and its robustness during summer drought.

In this study, we aim to elucidate the role of plant functional types in affecting $\mathrm{C}$ fluxes in a peatland during a drought event. Specifically, we performed a plant-removal experiment in order to explore how two dominant plant functional types, i.e., ericoid dwarfshrubs and graminoids, can affect the resistance and the recovery of $\mathrm{CO}_{2}$ uptake during and after a drought event.

\section{Materials and Methods}

\section{Field sampling and experimental setup}

In November 2009, 32 intact peat cores (diameter 22 $\mathrm{cm}$, depth $16 \mathrm{~cm}$ ) were collected from Tofte mose, Lille Vildmose Natural Park, Denmark $\left(56^{\circ} 50^{\prime} \mathrm{N}, 10^{\circ} 15^{\prime} \mathrm{E}\right)$. Half of the cores were taken from wet lawns, and half were taken from relatively dry hummocks in order to include the two dominant microhabitats. All cores were representative for the site and encompassed equal (i.e., within natural variation) amounts of three plant functional types (PFTs): Sphagnum mosses, graminoids, and evergreen ericoid shrubs (Chapin et al. 1996). In the lawns, Sphagnum cuspidatum Ehrh. ex Hoffm. was the dominant moss species, while the vascular plant community consisted of the graminoids Eriophorum angustifolium Honck. and Rhynchospora alba (L.), and the ericoids Erica tetralix L., Vaccinium oxycoccus L., and Andromeda polifolia L. In the hummocks, Sphagnum magellanicum Brid. and S. rubellum Wils. dominate the peat moss layer, while the vascular plant community consisted of the graminoid Eriophorum vaginatum L., and the ericoids E. tetralix, V. oxycoccus, A. polifolia, Empetrum nigrum L., and Calluna vulgaris (L.). The vascular plant cover ranged between $25-50 \%$ in both microhabitats.

After extraction, the cores were carefully placed in plastic containers (hereafter referred to as mesocosms), transported to Utrecht University, The Netherlands, and kept in a growth room $\left(20^{\circ} \mathrm{C} / 18^{\circ} \mathrm{C}\right.$ and $12 / 12 \mathrm{~h}$ day/ night, $70 \%$ relative humidity $[\mathrm{RH}], 400 \mathrm{ppm} \mathrm{CO}_{2}, 200$ $\mu \mathrm{mol}$ PAR $\cdot \mathrm{m}^{-2} \cdot \mathrm{s}^{-1}$ light intensity) for seven weeks to acclimate (acclimation period). Mesocosms were watered twice a week, using artificial rainwater (Garrels and Christ 1965), which was sprinkled over the vegetation to mimic an average precipitation of $\sim 2 \mathrm{~mm} / \mathrm{d}(730 \mathrm{~mm} / \mathrm{yr}$; cf. the region of Lille Vildmose NP; data available online) ${ }^{8}$ Additionally, water levels were kept constant at $2 \mathrm{~cm}$ and $10 \mathrm{~cm}$ below the Sphagnum capitula for lawns and hummocks, respectively, by funneling artificial rainwater to the mesocosms. One mesocosm became visibly infected with fungi and was removed from the experiment, resulting in 31 mesocosms (16 hummocks, 15 lawns).

After the acclimation period, vascular plant functional type (PFT) composition was manipulated by removing ericoids $\left(\mathrm{E}_{\mathrm{rem}}\right)$, graminoids $\left(\mathrm{G}_{\mathrm{rem}}\right)$, or both the PFTs so to leave a pure Sphagnum stand ( $n=4$ for each treatment and microhabitat). Removal was realized by clipping the aboveground biomass flush to the moss layer (McLellan et al. 1995). An extra set of mesocosms was used as a control treatment, but in order to take into account the potential effects of the clipping procedure, about $20 \%$ of the ericoid and graminoid cover was removed from the control mesocosms (Table 1). The period between PFT removal and the drought event lasted four weeks (pre-drought period), and was used to recover from the removal procedure. The second experimental period entailed the actual drought event (drought period), during which the mesocosms were allowed to dry out "naturally." After four weeks of drought, all mesocosms were rewetted and allowed to recover (recovery period). Rainwater was added to completely submerge the mesocosms over a one-night period, after which the water tables were brought back to their initial levels and the original pre-drought watering regime was resumed. The process of recovery was monitored for 10 weeks. Throughout all the experimental periods, the treatments were maintained by regular removal of regrown biomass.

\section{Carbon exchange measurements}

We used net ecosystem $\mathrm{CO}_{2}$ exchange (NEE) measurements to approximate net ecosystem productivity. Ecosystem respiration $\left(R_{\mathrm{e}}\right.$; autotrophic and heterotrophic) was measured by darkening the chambers. Closed flux chambers (diameter $20 \mathrm{~cm}$, height $29 \mathrm{~cm}$, fitted with a circulating fan) were placed over the mesocosms to measure $\mathrm{CO}_{2}$ fluxes using an Innova Bruel Kjær BK

\footnotetext{
${ }^{8}$ www.dmi.dk
} 
TABLE 1. Amounts of removed vascular plant aboveground biomass, and cover of the different plant functional types (PFT) after biomass removal for the PFT removal treatments on the lawn and hummock microhabitats.

\begin{tabular}{|c|c|c|c|c|c|c|}
\hline \multirow[b]{2}{*}{ Treatment } & \multirow{2}{*}{$\begin{array}{l}\text { Biomass removed } \\
\text { (g dry mass) }\end{array}$} & \multicolumn{4}{|c|}{ PFT cover after removal $(\%)$} & \multirow{2}{*}{$\begin{array}{c}\text { Total evapotranspiration } \\
\text { during the drought } \\
\text { period }\left(\mathrm{mL} / \mathrm{m}^{2}\right)\end{array}$} \\
\hline & & Sphagnum & Ericoids & Graminoids & Vascular plants & \\
\hline \multicolumn{7}{|l|}{ Lawn } \\
\hline Control & $0.95 \pm 0.3$ & $100 \pm 0$ & $15.0 \pm 3.5$ & $15.0 \pm 2.9$ & $30.0 \pm 3.5$ & $67.53^{\mathrm{a}} \pm 4.3$ \\
\hline $\mathrm{E}_{\mathrm{rem}}$ & $3.35 \pm 0.9$ & $100 \pm 0$ & $\ldots$ & $27.5 \pm 3.2$ & $27.5 \pm 3.2$ & $67.53^{\mathrm{a}} \pm 4.3$ \\
\hline $\mathrm{G}_{\mathrm{rem}}$ & $0.54 \pm 0.2$ & $100 \pm 0$ & $17.5 \pm 7.2$ & $\ldots$ & $17.5 \pm 7.2$ & $59.30^{\mathrm{a}} \pm 2.6$ \\
\hline $\mathrm{E}_{\mathrm{rem}}+\mathrm{G}_{\mathrm{rem}}$ & $3.91 \pm 0.3$ & $100 \pm 0$ & $\cdots$ & $\cdots$ & $\cdots$ & $60.58^{\mathrm{a}} \pm 4.3$ \\
\hline \multicolumn{7}{|l|}{ Hummock } \\
\hline Control & $1.93 \pm 0.7$ & $100 \pm 0$ & $20.8 \pm 2.9$ & $9.2 \pm 2.5$ & $30.0 \pm 1.6$ & $69.89^{\mathrm{ab}} \pm 2.5$ \\
\hline $\mathrm{E}_{\mathrm{rem}}$ & $4.50 \pm 0.7$ & $100 \pm 0$ & $\cdots$ & $17.1 \pm 3.0$ & $17.1 \pm 3.0$ & $61.36^{\mathrm{a}} \pm 1.7$ \\
\hline $\mathrm{G}_{\mathrm{rem}}$ & $0.12 \pm 0.1$ & $100 \pm 0$ & $21.3 \pm 3.5$ & $\ldots$ & $21.3 \pm 3.5$ & $72.64^{\mathrm{b}} \pm 1.8$ \\
\hline $\mathrm{E}_{\mathrm{rem}}+\mathrm{G}_{\mathrm{rem}}$ & $5.26 \pm 0.5$ & $100 \pm 0$ & $\ldots$ & $\ldots$ & $\ldots$ & $65.24^{\mathrm{ab}} \pm 3.2$ \\
\hline
\end{tabular}

Notes: Vascular plant functional type (PFT) composition was manipulated by removing ericoids $\left(\mathrm{E}_{\text {rem }}\right)$, graminoids $\left(\mathrm{G}_{\mathrm{rem}}\right)$, or both the PFTs so to leave a pure Sphagnum stand ( $n=4$ for each treatment and microhabitat). Note that in the control treatment, part of the ericoid and graminoid aboveground biomass has been removed in order to take into account the potential effects of the clipping procedure. Total evapotranspiration rates have been calculated over the drought period; significant differences (Tukey's post hoc test; $P \leq 0.05$ ) are indicated by different superscript letters. Ellipses indicate data not applicable.

1302 photoacoustic multi gas analyzer (type 1302; Bruel and Kjær, Nærum, Denmark), connected to a multipoint sampler (CBISS MK2, 4-channel; CBISS, Birkenhead, Merseyside, United Kingdom). During chamber closure, increment in air pressure in the chamber headspace was avoided by a $10-\mathrm{mm}$ opening at the top of the plastic container, which was closed before any records were taken. The chambers made no contact with the vegetation wherefore disturbance of pressure gradients across the soil-atmosphere interface was avoided. Chamber measurements comprised five succeeding sampling points with an eight-minute interval. NEE was measured weekly during the pre-drought period and every two days during the drought period. During the recovery period, measurements were initially performed every two days, but intensity was reduced at a later stage. $R_{\mathrm{e}}$ was measured just before and after plant removal, and throughout the drought period and recovery period. The ecological sign convention was used for the NEE and $R_{\mathrm{e}}$ data, so that positive fluxes indicate $\mathrm{CO}_{2}$ uptake and negative fluxes indicate $\mathrm{CO}_{2}$ loss to the atmosphere.

\section{Calculations and statistical analyses}

NEE was calculated from the change in $\mathrm{CO}_{2}$ concentration in the chamber headspace with time, using an exponential nonlinear function as proposed by Kutzbach et al. (2007). We used the nls function in the stats package in $\mathrm{R}$ to fit the models to the first four $\mathrm{CO}_{2}$ readings of the individual time series. In general, the coefficients of determination of the fitted models were very convenient ( $91 \%$ of the regressions showing an $r^{2}>$ $0.995, n=940$ ). The net $\mathrm{CO}_{2}$ flux was then calculated for the time zero, representing the flux at the start of the enclosure (see Appendix A for specifics). $R_{\mathrm{e}}$ was determined by a linear regression over the five succeeding sampling points after darkening the chambers.
The resistance to drought is the ability of the system to reduce the decrease of NEE throughout the drought period. Here, the resistance was calculated, for each individual mesocosm, as the slope of the linear regression through the NEE data points over the drought period. These regression parameters were also used to calculate the time when NEE switched from a positive to negative value (i.e., $\mathrm{NEE}=0$ ) for each individual mesocosm. Similar to our measure of resistance, the recovery was calculated using the slope through the NEE data points over the recovery period. Since NEE values decreased abruptly immediately after the recovery (data not shown), the use of a linear regression would not be appropriate. To circumvent this problem, recovery was calculated using the data collected one week after the start of the recovery period. Resilience was calculated as the ratio of post-recovery to pre-drought NEE. As such, resilience combines resistance and recovery and provides a measure of the extent to which the NEE has recovered to the pre-drought level.

To test the influence of our treatments on net ecosystem exchange (NEE) and ecosystem respiration $\left(R_{\mathrm{e}}\right)$, we used the generalized linear models (GLM) assuming a Gaussian distribution of the data. We coded microhabitat $(\mathrm{MH})$, ericoid removal $\left(\mathrm{E}_{\mathrm{rem}}\right)$, and graminoid removal $\left(\mathrm{G}_{\mathrm{rem}}\right)$ as binary factors, and initially we tested the treatment effect on NEE and $R_{\mathrm{e}}$ at three crucial moments during the experiment, i.e., just before the initiation of the drought period (pre-drought), at the end of the drought period (post-drought), and at the end of the recovery period (post-rewetting). Similarly, we tested the treatment effect on the resistance, recovery, and resilience of the net ecosystem exchange.

As the amount of removed biomass can be considered as an explanatory factor, we initially examined two models. The first model contained the factors $\mathrm{MH}, \mathrm{E}_{\mathrm{rem}}$, 

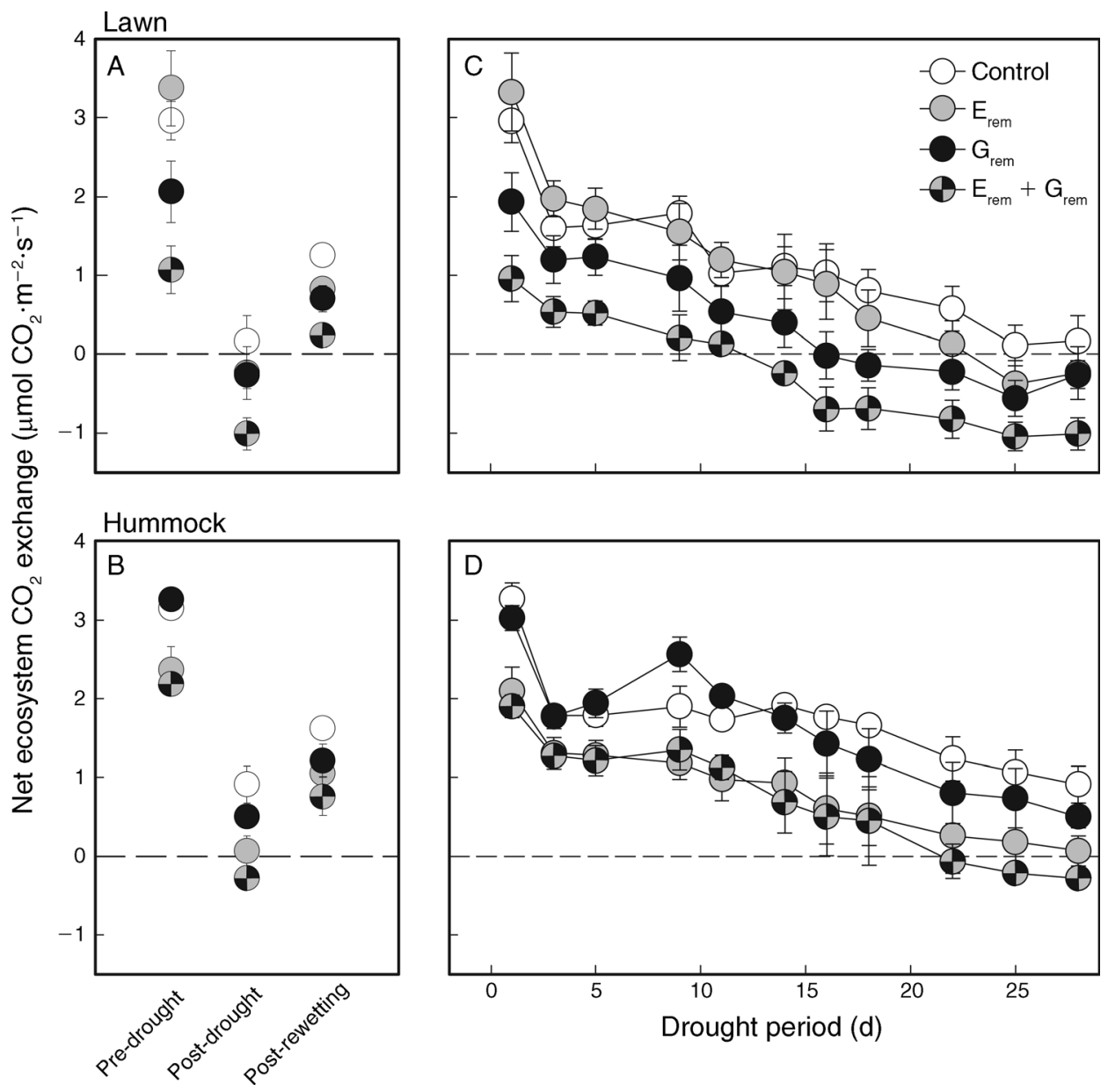

FIG. 1. Comparison of net ecosystem exchange (NEE; means \pm SE) rates between the different plant functional type removal at the pre-drought, post-drought, and post-recovery period in (A) lawns and (B) hummocks, as well as during the drought period in (C) lawns and (D) hummocks. Vascular plant functional type (PFT) composition was manipulated by removing ericoids ( $\mathrm{E}_{\text {rem }}$ ), graminoids $\left(\mathrm{G}_{\text {rem }}\right)$, or both to leave a pure Sphagnum stand $\left(\mathrm{E}_{\mathrm{rem}}+\mathrm{G}_{\mathrm{rem}} ; n=4\right.$ for each treatment and microhabitat). In the control treatment, only part $(\sim 20 \%)$ of the ericoid and graminoid aboveground biomass was removed in order to take into account the potential effects of the clipping procedure. For more information, see the Materials and methods section. Negative values indicate net $\mathrm{CO}_{2}$ loss. For statistics, see Appendices $\mathrm{C}$ and D.

and $\mathrm{G}_{\mathrm{rem}}$, while the second model considered the amount of "biomass removed" as co-variable. The goodness-of-fit in relation to the model complexity was evaluated by comparing values of the corrected Akaike information criterion $\left(\mathrm{AIC}_{\mathrm{c}}\right)$, using the selMod function in pgirmess package in R (Giraudoux 2013). The model with the smallest $\mathrm{AIC}_{\mathrm{c}}$ was selected, and further analyses were performed using the ANOVA function and the $F$ statistic in the stats package of $\mathrm{R}$. The lme package in $\mathrm{R}$ (Pinheiro et al. 2011) was used to perform repeatedmeasures ANOVA to determine the effects of $E_{\text {rem, }}$ $\mathrm{G}_{\text {rem }}$, and $\mathrm{MH}$ on NEE through the drought period and the recovery period. As microhabitats differed significantly in their $\mathrm{CO}_{2}$ exchange dynamics (significant $\mathrm{MH}$ effects, or $\mathrm{MH} \times \mathrm{E}_{\text {rem }}$ and $\mathrm{MH} \times \mathrm{G}_{\text {rem }}$ interactions; see also Appendix $\mathrm{C}$ and $\mathrm{D}$ ), these analyses were also performed separately for the two microhabitats. All analyses were performed with the software R 2.15.2 (R Development Core Team 2012).

\section{RESUlts}

Pre-drought period: the effect of vascular plant functional type removal

To test the potential role of the amount of removed biomass in affecting net ecosystem exchange (NEE) and ecosystem respiration $\left(R_{\mathrm{e}}\right)$, we examined the explanatory power of a set of models with different complexities (see Appendix B). The amount of removed biomass was rather important for the change in NEE and $R_{\mathrm{e}}$ before and after plant functional type (PFT) removal. Therefore, the co-variable "biomass removed" was always taken into the potential models when testing for the effects on PFT removal in further analyses. 


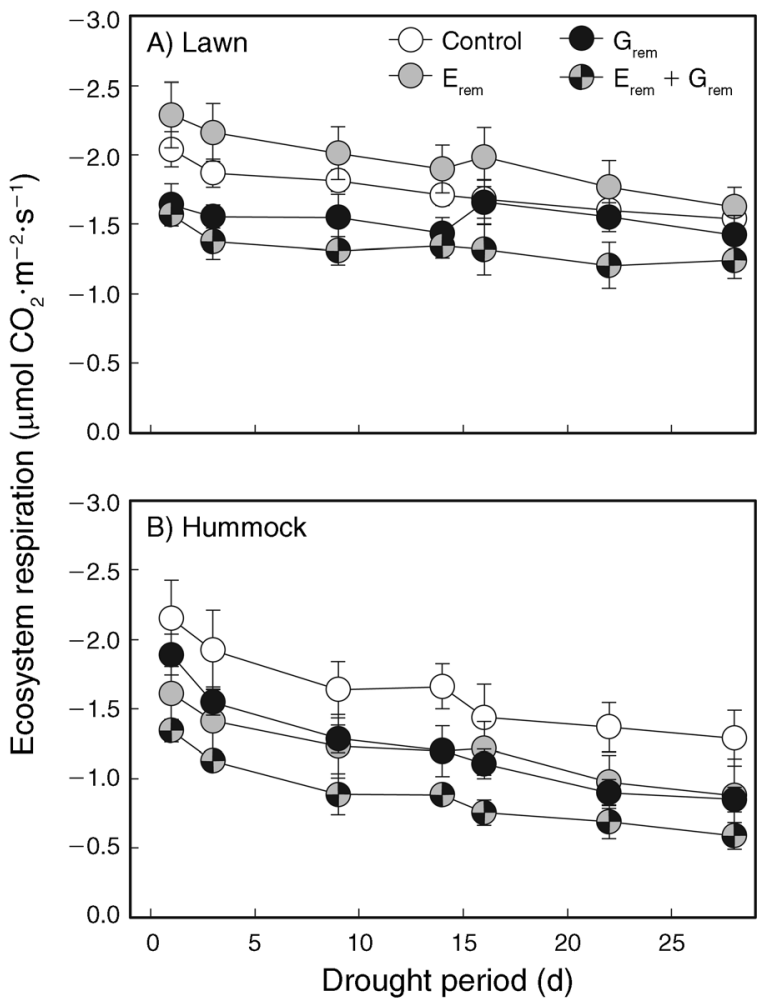

FIG. 2. The effect of plant functional type removal on ecosystem respiration during the drought period in (A) lawns and (B) hummocks. Negative values indicate net $\mathrm{CO}_{2}$ loss. For statistics, see Appendix D. Shown are means \pm SE.

Plant functional type (PFT) removal caused a decrease in pre-drought NEE, which differed between the microhabitats in relation to the PFTs (Fig. 1A, B; Appendix C). Indeed, in the lawns, graminoid removal reduced $\operatorname{NEE}\left(F_{1,12}=16.9, P \leq 0.01\right)$. Ericoid removal caused a reduction of NEE only in combination with graminoid removal (ericoid $\times$ graminoid $F_{1,11}=3.5, P=$ 0.09). In the hummocks, ericoid removal resulted in a reduction of $\operatorname{NEE}\left(F_{1,14}=27.3, P \leq 0.001\right)$, whereas graminoid removal did not affect the NEE. Including removed biomass in these GLM model did not enhance the explanatory power, i.e., higher $\mathrm{AIC}_{\mathrm{c}}$ (Appendix C).

\section{Drought period: the resistance to drought}

Net ecosystem exchange (NEE) and ecosystem respiration $\left(R_{\mathrm{e}}\right)$ decreased immediately after the start of the experimental drought in all the mesocosms (Figs. 1 and 2). The resistance to drought differed between microhabitats (Fig. 3A, B, Table 2). The decrease of NEE was faster in the lawns, resulting in lower postdrought NEE (Fig. 1; Appendices C and D). In fact, lawns switched from $\mathrm{CO}_{2}$ sinks $(\mathrm{NEE}>0)$ to $\mathrm{CO}_{2}$ sources $(\mathrm{NEE}<0)$ earlier than hummocks (Figs. 1 and 3C, D, Table 2). The decrease of $R_{\mathrm{e}}$ was faster in the hummocks (Fig. 2; Appendix D).
PFT removal did not significantly affect the resistance in both microhabitats (Table 2), though in the lawn microhabitats, graminoid removal seemed to slightly slow down the decrease in $\operatorname{NEE}\left(F_{1,12}=3.4, P=0.09\right)$, and, although not significant, the removal of ericoids seemed to slightly speed up the decrease of NEE. Nevertheless, PFT removal affected the moment of the switch from $\mathrm{CO}_{2}$ sink to $\mathrm{CO}_{2}$ source in the two
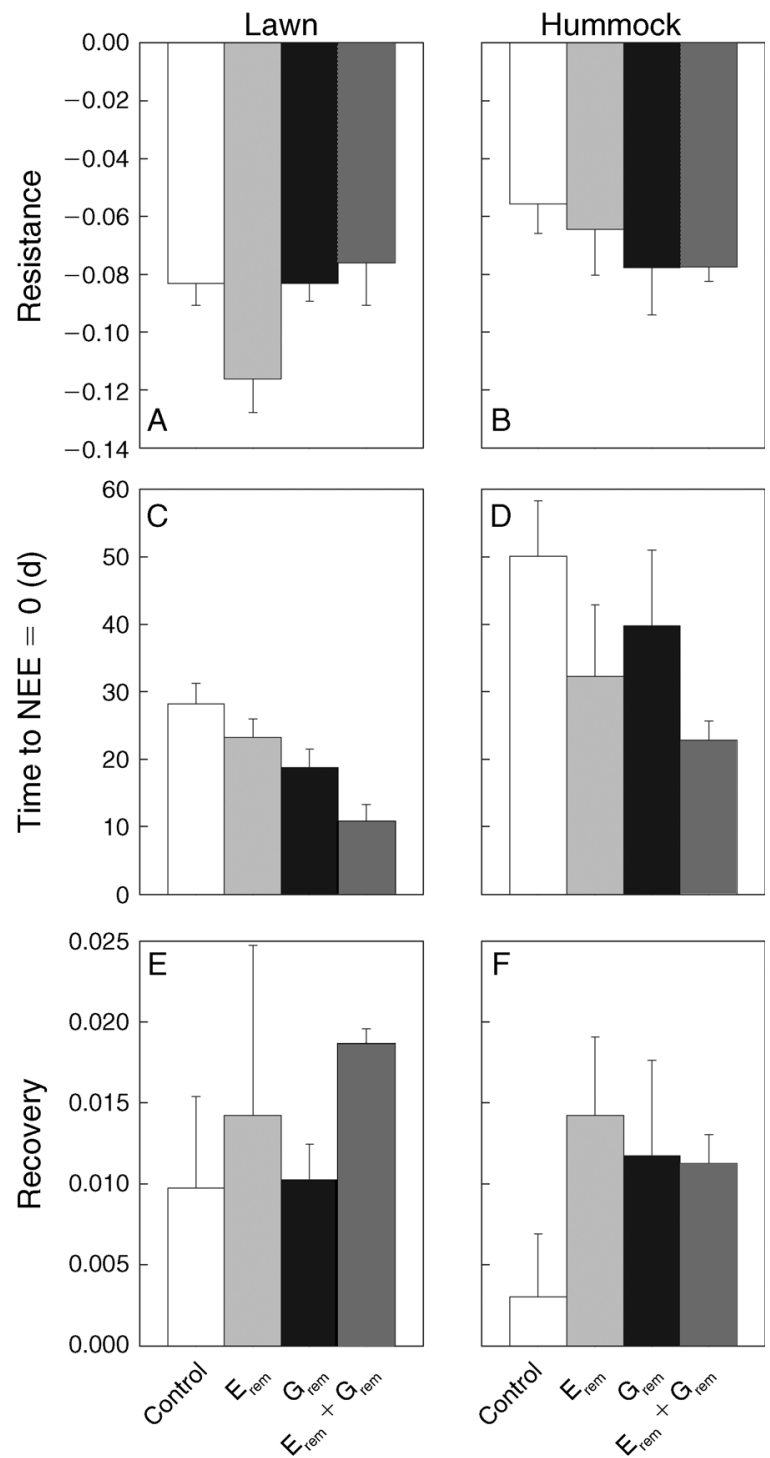

FIG. 3. The effect of plant functional type removal on $(\mathrm{A}, \mathrm{B})$ the resistance, $(\mathrm{C}, \mathrm{D})$ the time to net ecosystem $\mathrm{CO}_{2}$ exchange (NEE) to equal zero, and $(\mathrm{E}, \mathrm{F})$ the recovery in the two microhabitats. "Resistance" was defined as the mesocosms' ability to reduce the decrease of NEE throughout the drought period; "NEE $=0$ " defined the point in time where the mesocosms switched from $\mathrm{CO}_{2}$ uptake to $\mathrm{CO}_{2}$ release; and "recovery" was defined as the ability of a mesocosm to convalesce its $\mathrm{CO}_{2}$ uptake. For clarification of the abbreviations, see Fig. 1; for more information, see the Materials and methods section. Shown are means $\pm \mathrm{SE}$. 
TABLE 2. ANOVA results for the interactive effects of microhabitat, ericoid removal, and graminoid removal on the recovery of net ecosystem $\mathrm{CO}_{2}$ exchange (NEE) and resistance, time to $\mathrm{NEE}=0$.

\begin{tabular}{|c|c|c|c|c|c|c|c|c|c|}
\hline \multirow[b]{2}{*}{ Factor } & \multirow[b]{2}{*}{ df } & \multicolumn{2}{|c|}{ Resistance NEE } & \multicolumn{2}{|c|}{$\mathrm{NEE}=0$} & \multicolumn{2}{|c|}{ Recovery NEE } & \multicolumn{2}{|c|}{ Resilience NEE } \\
\hline & & $F$ & $P$ & $F$ & $P$ & $F$ & $P$ & $F$ & $P$ \\
\hline Microhabitat (MH) & 1,29 & 7.1 & $\leq \mathbf{0 . 0 5}$ & 11.6 & $\leq \mathbf{0 . 0 1}$ & 0.5 & 0.48 & 0.6 & 0.44 \\
\hline $\mathrm{E}_{\mathrm{rem}}$ & 1,28 & 1.4 & 0.24 & 6.1 & $<0.05$ & 2.2 & 0.15 & 0.7 & 0.41 \\
\hline $\mathrm{G}_{\text {rem }}$ & 1,27 & 0.0 & 1.00 & 4.5 & $\leq \mathbf{0 . 0 5}$ & 0.4 & 0.51 & 0.9 & 0.34 \\
\hline $\mathrm{MH} \times \mathrm{E}_{\mathrm{rem}}$ & 1,26 & 0.5 & 0.49 & 1.3 & 0.26 & 0.0 & 0.90 & 0.0 & 0.91 \\
\hline $\mathrm{MH} \times \mathrm{G}_{\mathrm{rem}}$ & 1,25 & 4.9 & $\leq \mathbf{0 . 0 5}$ & 0.1 & 0.78 & 0.0 & 0.94 & 0.5 & 0.47 \\
\hline $\mathrm{E}_{\mathrm{rem}} \times \mathrm{G}_{\mathrm{rem}}$ & 1,24 & 2.1 & 0.16 & 0.1 & 0.77 & 0.3 & 0.59 & 0.5 & 0.48 \\
\hline $\mathrm{MH} \times \mathrm{E}_{\mathrm{rem}}: \mathrm{G}_{\mathrm{rem}}$ & 1,23 & 0.9 & 0.35 & 0.0 & 0.99 & 1.0 & 0.32 & 0.2 & 0.66 \\
\hline
\end{tabular}

Notes: $P$ values shown in boldface type indicate significant values. "Resistance" was defined as the mesocosms' ability to reduce the decrease of NEE throughout the drought period; "NEE $=0$ " defined the point in time where the mesocosms switched from $\mathrm{CO}_{2}$ uptake to $\mathrm{CO}_{2}$ release; and "recovery" was defined as the ability of the mesocosms to convalesce its $\mathrm{CO}_{2}$ uptake.

microhabitats (Fig. 3C, D, Table 2). When analyzed separately, it appears that, in the lawn microhabitats, graminoid removal caused an earlier switch of the ecosystem from $\mathrm{CO}_{2}$ sink to $\mathrm{CO}_{2}$ source $\left(F_{1,12}=14.4, P\right.$ $\leq 0.01$, while in the hummock, a microhabitat's ericoid removal enhanced such a switch, although not significantly $\left(F_{1,12}=3.9, P=0.07\right)$.

\section{Recovery after, and resilience to drought}

Rewetting caused a sudden increase in $\mathrm{CO}_{2}$ emission in all the mesocosms (data not shown). After this initial "desaturation respiration" (Gerdol et al. 1996), $\mathrm{CO}_{2}$ uptake recommenced relatively fast. On the whole, recovery was not influenced by the PFTs, although mesocosms without ericoids seemed to recover faster (Fig. 3E, F, Table 2), especially in the lawn microhabitats. Ecosystem resilience differed between microhabitats (Table 2), and was higher in the hummocks $(45 \% \pm$ $6.3 \%)$ than in the lawns $(25 \% \pm 4.6 \%$ [means $\pm \mathrm{SEM}])$. In both microhabitats, the PFT removal treatment did not affect the resilience of NEE (Table 2).

\section{DisCUSSION}

Using a plant-removal experiment, we tested the role of vascular plant functional types on short-term $\mathrm{CO}_{2}$ fluxes in peatland in response to drought. Removal experiments are useful to study the relation between plant functional types and ecosystem processes (Diaz et al. 2003), although we acknowledge they have their limitations (Bret-Harte et al. 2004, Ward et al. 2009, Gundale et al. 2010). Remaining plant roots, for example, may increase ecosystem respiration $\left(R_{\mathrm{e}}\right)$, and concomitantly decrease net ecosystem exchange (NEE). We, however, observed decreased $R_{\mathrm{e}}$ after vascular PFT removal, confirming the contribution of vascular plant biomass to ecosystem respiration in peatlands (Bubier et al. 2003). Interestingly, the decrease in NEE upon PFT removal was trait dependent and different between lawns and hummocks. Indeed, decreased NEE in hummocks was mainly caused by the removal of ericoids, whereas in lawns, it was mainly caused by graminoid removal (Fig. 1). The decrease in NEE due to plant removal can partly be explained by the amount of removed biomass (Appendix B), yet the effects of PFT removal and biomass removal are highly collinear, i.e., hummocks are dominated by ericoids, while lawns are dominated by graminoids. Contrasting to our results, Ward et al. (2009) did not find any change in NEE after ericoid or graminoid removal from a blanket bog, due to an increase of both the gross $\mathrm{C}$ uptake and respiration rate. We argue that the removal of the high cover $(\sim 70 \%)$ of vascular plants in their experiment may have stimulated the photosynthetic rates of the underlying moss layer. This apparent "competitive release effect" (Wardle et al. 1999, Symstad and Tilman 2001) did not take place in our experiment where the initial cover of vascular plants was much lower (25-50\%). Concurrently, negative effects of vascular plant cover on underlying mosses or soil processes have been reported to occur mainly at dense vascular plant cover (Chapin and Shaver 1985, Heijmans et al. 2002, Blok et al. 2011).

Our findings that NEE decreased with plant removal indicate an important role of vascular plants and their corresponding traits in affecting NEE (McNeil and Waddington 2003), yet the overall aim of this study was to elucidate the role of PFTs on the resistance of NEE to, and its recovery after an extreme summer drought. The decrease in NEE during the drought period in all treatments indicates an intrinsic sensitivity of peatlands to drought (Cai et al. 2010, Fenner and Freeman 2011, Lund et al. 2012). Lawns were less resistant to drought than hummocks (Fig. 3), supporting earlier findings of greater resistance of hummock Sphagnum species to desiccation (Andrus 1986, Strack and Price 2009). While vascular plant species seem to be important in controlling levels of NEE, they seem not to play an important role in mitigating the negative effect of drought on NEE. This is surprising, as vascular plants can avoid desiccation during drought by actively regulating their water content through morphological adaptations (roots, stomata, vascular system). Sphagnum mosses are poikilohdyric and cannot actively control their water contents. They can only tolerate drought through physiological responses, like quenching basal chlorophyll fluorescence (Hájek and Beckett 2008, Turetsky et al. 2012). Based on the absence of an effect of PFTs on 
the resistance to drought (Table 2), we reason that the decrease of NEE is primarily controlled by the droughtinduced decrease of Sphagnum photosynthetic assimilation. Indeed, most mesocosms were visibly desiccated toward the end of the drought period (Robroek et al. 2009). Would we, however, approach resistance as the ecosystem's capacity to maintain positive $\mathrm{CO}_{2}$ uptake during drought (i.e., time to NEE $\leq 0$ ), the presence of vascular plants becomes rather important (Fig. 3). According to previous hypotheses from grassland studies (Wang et al. 2007, van Ruijven and Berendse 2009), the initial productivity (or NEE), and not the plant functional type diversity per se, then determines the resistance of the peatland to environmental perturbations.

The observed recovery after drought resembles that already presented by Robroek et al. (2009). They, however, report data from pure Sphagnum stands. Interestingly, Sphagnum mosses are generally described as a drought intolerant genus, being very sensitive to (repeated) desiccation (Gerdol et al. 1996, Schipperges and Rydin 1998) and slow in their recovery after drought (Gerdol et al. 1996, Bragazza 2008). The faster recovery observed in hummocks indicates a greater tolerance to desiccation of hummock Sphagnum mosses (Hájek and Beckett 2008). Our results, however, show that after a 10 -week recovery period, $\mathrm{CO}_{2}$ uptake returned only to $<45 \%$ of the pre-drought perturbation levels. Although our results indicate a relatively swift recovery of $\mathrm{C}$ uptake after a drought, these results also indicate that a single drought can have a substantial impact on the annual $\mathrm{CO}_{2}$ budget (Alm et al. 1999). In fact, any cessation in carbon uptake can have a strong effect on the annual $\mathrm{C}$ budget in peatlands (McNeil and Waddington 2003). The size of this effect depends on the timing, the severity and the duration of the drought (Lund et al. 2012).

The apparent absence of a crucial role for PFT composition on the resistance to, and recovery after, a drought in peatlands, together with the response of net photosynthesis of monospecific Sphagnum stands to drought (Robroek et al. 2009, Adkinson and Humphreys 2011), indicate a dominant mechanistic role for the Sphagnum community. Raised bogs have a rather low diversity and are characterized by the presence of a clear ecosystem engineer, which may have a disproportionate influence on ecosystem processes (Brown 1995, Polley et al. 2007). Consequently, Sphagnum mosses largely control the ecosystem $\mathrm{C}$ cycling. Such a strong effect displayed by a single group has been earlier reported as a possible explanation for the absence of diversity-ecosystem functioning relationships (Hooper et al. 2005). As in peatlands, Sphagnum mosses have the largest share of the aboveground green biomass in all plant communities (Laine et al. 2012), our results support Grime's biomass ratio hypothesis (Grime 1998), which states that the effect of each species or plant functional group is proportional to its relative biomass in the ecosystem.

Changes in short-term $\mathrm{CO}_{2}$ fluxes due to drought are of relevance for the long-term $\mathrm{C}$ budget of peatlands (Ward et al. 2009), especially if extreme drought events are expected to occur more often (Dai 2012). Our study shows that vascular PFTs do not affect the resistance of the peatland ecosystem to, nor the recovery after, an experimental drought. Nevertheless, vascular PFTs are important in controlling net ecosystem productivity, and thereby the moment the systems can switch from $\mathrm{C}$ sink to $\mathrm{C}$ source during a drought event. As evidenced by our data, the presence of vascular plants secures the $\mathrm{C}$ sink function during drought events in both lawns and hummocks. In the light of climate change, shifts in the species community composition or even the loss of certain PFTs can thus have strong effects on future $\mathrm{C}$ dynamics in response to environmental stress.

\section{ACKNOWLEDGMENTS}

The Lille Vildmose area is owned and conserved by the Aage V. Jenssen Foundation (Denmark), and we appreciate their permission, arranged through Jacob Pålsgaard, to enter the reserve and collect samples. This paper was greatly improved by the comments of two anonymous referees. We are also grateful to Alexandre Buttler, Mariet Hefting, Constant Signarbieux, and Jasper van Ruijven for many valuable suggestions on the presentation of our results. The Division for Earth and Life Sciences (ALW) with financial aid from the Netherlands Organization for Scientific Research (NWO; Research Innovation Scheme grant number 863.10.014) supports this work.

\section{Literature Cited}

Adkinson, A. C., and E. R. Humphreys. 2011. The response of carbon dioxide exchange to manipulations of Sphagnum water content in an ombrotrophic bog. Ecohydrology 4:733743.

Alm, J., L. Schulman, J. Walden, H. Nykänen, P. J. Martikainen, and J. Silvola. 1999. Carbon balance of a boreal bog during a year with an exceptionally dry summer. Ecology 80: $161-174$

Andrus, R. E. 1986. Some aspects of Sphagnum ecology. Canadian Journal of Botany 64:416-426.

Backéus, I. 1972. Bog vegetation re-mapped after sixty years, studies on Skagershultamossen, central Sweden. Oikos 384393.

Blok, D., M. M. P. D. Heijmans, G. Schaepman-Strub, J. Ruijven, F. J. W. Parmentier, T. C. Maximov, and F. Berendse. 2011. The cooling capacity of mosses: controls on water and energy fluxes in a Siberian tundra site. Ecosystems 14:1055-1065.

Bloor, J. M. G., and R. D. Bardgett. 2012. Stability of aboveground and below-ground processes to extreme drought in model grassland ecosystems: Interactions with plant species diversity and soil nitrogen availability. Perspectives in Plant Ecology, Evolution and Systematics 14:193-204.

Bragazza, L. 2008. A climatic threshold triggers the die-off of peat mosses during an extreme heat wave. Global Change Biology 14:2688-2695.

Bragazza, L., and C. Freeman. 2007. High nitrogen availability reduces polyphenol content in Sphagnum peat. Science of the Total Environment 377:439-443.

Bret-Harte, M. S., E. A. García, V. M. Sacré, J. R. Whorley, J. L. Wagner, S. C. Lippert, and F. S. Chapin, III. 2004. Plant and soil responses to neighbour removal and fertiliza- 
tion in Alaskan tussock tundra. Journal of Ecology 92:635647.

Brown, J. H. 1995. Organisms as engineers: a useful framework for studying effects on ecosystems? Trends in Ecology and Evolution 10:51-52.

Bubier, J., P. Crill, A. Mosedale, S. Frolking, and E. Linder. 2003. Peatland responses to varying interannual moisture conditions as measured by automatic $\mathrm{CO}_{2}$ chambers. Global Biogeochemical Cycles 17:1066.

Cai, T., L. B. Flanagan, and K. H. Syed. 2010. Warmer and drier conditions stimulate respiration more than photosynthesis in a boreal peatland ecosystem: analysis of automatic chambers and eddy covariance measurements. Plant, Cell and Environment 33:394-407.

Chapin, F. S., III, M. S. Bret Harte, S. E. Hobbie, and H. Zhong. 1996. Plant functional types as predictors of transient responses of arctic vegetation to global change. Journal of Vegetation Science 7:347-358.

Chapin, F. S., III, and G. R. Shaver. 1985. Individualistic growth response of tundra plant species to environmental manipulations in the field. Ecology 66:564-576.

Craine, J. M., T. W. Ocheltree, J. B. Nippert, E. G. Towne, A. M. Skibbe, S. W. Kembel, and J. E. Fargione. 2012. Global diversity of drought tolerance and grassland climatechange resilience. Nature Climate Change 3:63-67.

Dai, A. 2012. Increasing drought under global warming in observations and models. Nature Climate Change 3:52-58.

Deppe, M., K. H. Knorr, D. M. McKnight, and C. Blodau. 2010. Effects of short-term drying and irrigation on $\mathrm{CO}_{2}$ and $\mathrm{CH}_{4}$ production and emission from mesocosms of a northern bog and an alpine fen. Biogeochemistry 100:89-103.

Dias, A., M. P. Berg, F. Bello, A. R. van Oosten, K. Bílá, and M. Moretti. 2013. An experimental framework to identify community functional components driving ecosystem processes and services delivery. Journal of Ecology 101:29-37.

Diaz, S., A. J. Symstad, F. S. Chapin, III, D. A. Wardle, and L. F. Huenneke. 2003. Functional diversity revealed by removal experiments. Trends in Ecology and Evolution 18: $140-146$.

Dorrepaal, E., S. Toet, R. S. P. van Logtestijn, E. Swart, M. J. Van De Weg, T. V. Callaghan, and R. Aerts. 2009. Carbon respiration from subsurface peat accelerated by climate warming in the subarctic. Nature 460:616-619.

Fenner, N., and C. Freeman. 2011. Drought-induced carbon loss in peatlands. Nature Geoscience 4:895-900.

Freeman, C., C. D. Evans, D. T. Monteith, B. Reynolds, and N. Fenner. 2001a. Export of organic carbon from peat soils. Nature 412:785.

Freeman, C., N. Ostle, and H. Kang. 2001b. An enzymic "latch" on a global carbon store. Nature 409:149.

Garrels, R. M., and C. L. Christ. 1965. Solutions, minerals and equilibria. Jones and Bartlett, Boston, Massachusetts, USA.

Gerdol, R., A. Bonora, R. Gualandri, and S. Pancaldi. 1996. $\mathrm{CO}_{2}$ exchange, photosynthetic pigment composition, and cell ultrastructure of Sphagnum mosses during dehydration and subsequent rehydration. Canadian Journal of Botany 74: 726-734.

Giraudoux, P. 2013. pgirmess: Data analysis in ecology. R package version 1.5.7. R Foundation for Statistical Computing, Vienna, Austria. http://CRAN.R-project.org/ package=pgirmess

Grime, J. P. 1998. Benefits of plant diversity to ecosystems: immediate, filter and founder effects. Journal of Ecology 86: 902-910.

Gundale, M. J., D. A. Wardle, and M.-C. Nilsson. 2010. Vascular plant removal effects on biological $\mathrm{N}$ fixation vary across a boreal forest island gradient. Ecology 91:1704-1714.

Hájek, T., S. Ballance, J. Limpens, M. Zijlstra, and J. T. A. Verhoeven. 2011. Cell-wall polysaccharides play an important role in decay resistance of Sphagnum and actively depressed decomposition in vitro. Biogeochemistry 103:45-57.
Hájek, T., and R. P. Beckett. 2008. Effect of water content components on desiccation and recovery in Sphagnum mosses. Annals of Botany 101:165-173.

Hector, A., et al. 2010. General stabilizing effects of plant diversity on grassland productivity through population asynchrony and overyielding. Ecology 91:2213-2220.

Heijmans, M. M. P. D., W. J. Arp, and F. S. Chapin, III. 2004. Controls on moss evaporation in a boreal black spruce forest. Global Biogeochemical Cycles 18:GB2004.

Heijmans, M. M. P. D., H. Klees, and F. Berendse. 2002. Competition between Sphagnum magellanicum and Eriophorum angustifolium as affected by raised $\mathrm{CO}_{2}$ and increased $\mathrm{N}$ deposition. Oikos 97:415-425.

Hooper, D. U., et al. 2005. Effects of biodiversity on ecosystem functioning: a consensus of current knowledge. Ecological Monographs 75:3-35.

Isbell, F., et al. 2011. High plant diversity is needed to maintain ecosystem services. Nature 477:199-202.

Johnson, D., J. Vachon, A. J. Britton, and R. C. Helliwell. 2011. Drought alters carbon fluxes in alpine snowbed ecosystems through contrasting impacts on graminoids and forbs. New Phytologist 190:740-749.

Kutzbach, L., J. Schneider, T. Sachs, M. Giebels, H. Nykänen, N. J. Shurpali, P. J. Martikainen, J. Alm, and M. Wilmking. 2007. $\mathrm{CO}_{2}$ flux determination by closed-chamber methods can be seriously biased by inappropriate application of linear regression. Biogeosciences 4:1005-1025.

Lafleur, P. M., N. T. Roulet, J. L. Bubier, S. Frolking, and T. R. Moore. 2003. Interannual variability in the peatlandatmosphere carbon dioxide exchange at an ombrotrophic bog. Global Biogeochemical Cycles 17:1036.

Laine, A. M., J. Bubier, T. Riutta, M. B. Nilsson, T. R. Moore, H. Vasander, and E. S. Tuittila. 2012. Abundance and composition of plant biomass as potential controls for mire net ecosystem $\mathrm{CO}_{2}$ exchange. Botany 90:63-74.

Laine, A., D. Wilson, G. Kiely, and K. A. Byrne. 2007. Methane flux dynamics in an Irish lowland blanket bog. Plant and Soil 299:181-193.

Loreau, M., and C. de Mazancourt. 2013. Biodiversity and ecosystem stability: a synthesis of underlying mechanisms. Ecology Letters 16:106-115.

Lund, M., T. R. Christensen, and A. Lindroth. 2012. Effects of drought conditions on the carbon dioxide dynamics in a temperate peatland. Environmental Research Letters 7: 045704.

McLellan, A. J., A. H. Fitter, and R. Law. 1995. On decaying roots, mycorrhizal colonization and the design of removal experiments. Journal of Ecology 225-230.

McNeil, P., and J. M. Waddington. 2003. Moisture controls on Sphagnum growth and $\mathrm{CO}_{2}$ exchange on a cutover bog. Journal of Applied Ecology 40:354-367.

Mulder, C. P., D. D. Uliassi, and D. F. Doak. 2001. Physical stress and diversity-productivity relationships: the role of positive interactions. Proceedings of the National Academy of Sciences USA 98:6704-6708.

Murray, K. J., J. D. Tenhunen, and J. Kummerow. 1989. Limitations on Sphagnum growth and net primary production in the foothills of the Philip Smith Mountains, Alaska. Oecologia 80:256-262.

Murray, K. J., J. D. Tenhunen, and R. S. Nowak. 1993. Photoinhibition as a control on photosynthesis and production of Sphagnum mosses. Oecologia 96:200-207.

Otieno, D. O., M. Wartinger, A. Nishiwaki, M. Z. Hussain, J. Muhr, W. Borken, and G. Lischeid. 2009. Responses of $\mathrm{CO}_{2}$ exchange and primary production of the ecosystem components to environmental changes in a mountain peatland. Ecosystems 12:590-603.

Piao, S., et al. 2008. Net carbon dioxide losses of northern ecosystems in response to autumn warming. Nature 451:4952. 
Pinheiro, J., D. Bates, S. DebRoy, D. Sarkar, and the R Development Core Team. 2011. nlme: Linear and nonlinear mixed effects models. $\mathrm{R}$ package version 3.1-102. $\mathrm{R}$ Foundation for Statistical Computing, Vienna, Austria.

Polley, H. W., B. J. Wilsey, and J. D. Derner. 2007. Dominant species constrain effects of species diversity on temporal variability in biomass production of tallgrass prairie. Oikos 116:2044-2052.

R Development Core Team. 2012. R: a language and environment for statistical computing. $\mathrm{R}$ Foundation for Statistical Computing, Vienna, Austria. URL http://www. R-project.org/

Robroek, B. J. M., J. Limpens, A. Breeuwer, and M. G. C. Schouten. 2007. Effects of water level and temperature on performance of four Sphagnum mosses. Plant Ecology 190: 97-107.

Robroek, B. J. M., M. G. C. Schouten, J. Limpens, F. Berendse, and H. Poorter. 2009. Interactive effects of water table and precipitation on net $\mathrm{CO}_{2}$ assimilation of three cooccurring Sphagnum mosses differing in distribution above the water table. Global Change Biology 15:680-691.

Rochefort, L. 2000. Sphagnum: A keystone genus in habitat restoration. Bryologist 103:503-508.

Rydin, H., and K. E. Barber. 2001. Long-term and fine-scale coexistence of closely related species. Folia Geobotanica 36: 53-61.

Rydin, H., and J. K. Jeglum. 2006. The biology of peatlands. Oxford University Press, New York, New York, USA.

Schipperges, B., and H. Rydin. 1998. Response of photosynthesis of Sphagnum species from contrasting microhabitats to tissue water content and repeated desiccation. New Phytologist 140:677-684.
Strack, M., and J. S. Price. 2009. Moisture controls on carbon dioxide dynamics of peat-Sphagnum monoliths. Ecohydrology 2:34-41.

Symstad, A. J., and D. Tilman. 2001. Diversity loss, recruitment limitation, and ecosystem functioning: lessons learned from a removal experiment. Oikos 92:424-435.

Turetsky, M. R., B. Bond-Lamberty, E. Euskirchen, J. Talbot, S. Frolking, A. D. McGuire, and E. S. Tuittila. 2012. The resilience and functional role of moss in boreal and arctic ecosystems. New Phytologist 196:49-67.

van Breemen, N. 1995. How Sphagnum bogs down other plants. Trends in Ecology and Evolution 10:270-275.

van Ruijven, J., and F. Berendse. 2009. Diversity enhances community recovery, but not resistance, after drought. Journal of Ecology 98:81-86.

Wang, Y., S. Yu, and J. Wang. 2007. Biomass-dependent susceptibility to drought in experimental grassland communities. Ecology Letters 10:401-410.

Ward, S. E., R. D. Bardgett, N. P. McNamara, and N. J. Ostle. 2009. Plant functional group identity influences short-term peatland ecosystem carbon flux: evidence from a plant removal experiment. Functional Ecology 23:454-462.

Wardle, D. A., K. I. Bonner, G. M. Barker, G. W. Yeates, K. S. Nicholson, R. D. Bardgett, R. N. Watson, and A. Ghani. 1999. Plant removals in perennial grassland: vegetation dynamics, decomposers, soil biodiversity, and ecosystem properties. Ecological Monographs 69:535-568.

Weltzin, J. F., S. D. Bridgham, J. Pastor, J. Chen, and C. Harth. 2003. Potential effects of warming and drying on peatland plant community composition. Global Change Biology 9:141-151.

\section{Supplemental Material}

\section{Appendix A}

Description of the exponential nonlinear model used for calculating $\mathrm{CO}_{2}$ fluxes from the mesocosms (Ecological Archives E095-011-A1).

\section{Appendix B}

The effects of biomass removal on net ecosystem $\mathrm{CO}_{2}$ exchange (NEE) and ecosystem respiration $\left(R_{\mathrm{e}}\right)$ (Ecological Archives E095-011-A2).

\section{Appendix C}

Model test results for two models, one with and one without "removed biomass" as a factor (Ecological Archives E095-011-A3).

\section{Appendix D}

Test results of the repeated-measures ANOVA on net ecosystem $\mathrm{CO}_{2}$ exchange during the drought period (Ecological Archives E095-011-A4). 